\title{
ANGIOGRAPHIC PREDICTION OF RECURRENCE IN RECTAL CARCINOMA
}

\author{
REKTAL KANSERLERDE NÜKSÜN ANJIOGRAFIYLE ÖNCEDEN \\ BELIRLENMESI
}

Toshihide IIIIMA

\section{SUMMARY}

Inferior mesenteric angiography was performed on 41 patients with rectal carcinoma and 28 of them were followed up for postoperative recurrence. Angiographic findings were classified into 4 groups: $\mathrm{A} G-\mathbf{A O}, \mathbf{A G}-\mathbf{A} 2$ and $\mathbf{A G}-\mathbf{A} 3$.

1) The recurrence rates of $\mathbf{A G}=\mathbb{A} 0, \mathbb{A} G-\mathbb{1}, \mathbb{A G}-\mathbf{A} 2$ and $\mathbb{A G}-\mathbb{A} 3$ are $0 \%, 25.0 \%, 25.0 \%$ and $50,0 \%$ 。

2) The histological adventitial, venous and lymphatic invasions in $A G$-A3 were very high.

3) There is not a clear difference in the histological invasions between $A G=A 1$ and $A G=A 2$ $(50.0-58.3 \%)$.

4) In the case of $\mathrm{AG}-\mathrm{AO}$, only venous invasion (50.0\%) was positive.

(Key Words: Angiography, Rectal Carcinoma, Recurrence)

\section{ÖZET}

41 rektal kanserli hastada inferior mezenterik anjiografi uyguland. Reseke edilebilen 28 'i postoperatif nüks açısından izlendi. Anjiografi bulguları 0, 1, 2 ve 3 olarak derecelendirildi. Sonuçta:

1) Nüks oranlari 0, 1, 2 ve 3 için ( $\% 0, \% 25, \% 25$ ve $\% 50)$ bulundu.

2) Histopatolojik tetkikte 3 . derecedeki olgularda adventisya, lenfatik ve venöz invazyon çok ileriydi.

3) Histolojik invazyon bakımından 1 ve 2. dereceler arasinda fark yok idi ( $\% 50.0$ ve \% 58.3).

4) 0. derecedeki olgularda venöz invazyon (\% 50) idi.

(Anahtar Sözcükler: Anjiografi, Nüks, Rektal Karsinom) 
There are many patients suffering from the rectal carcinoma after abdominoperineal resection. The rates of the recurrence in most of the series are $3-37 \%(1,2,3)$. Recently, many reports about CT diagnosis for the recurrence have appeared, but almost all of them have discussed the diagnosis for the existence of the recurrence after the operation $(4,5,6,7)$. Besides, there are no articles predicting the recurrence of the resected patients preoperatively. Under the present circumstances, we have a few modalities to diagnose the cancer invasion to the outside of the rectum (8). If the recurrence could be forecasted preoperatively, we would be able to cope with the recurrence by more radical resection, postoperative local radiation (9) and chemotherapy. Thus in this report we tried to predict the incidence of the recurrence on postoperative cases in the course of the follow up period.

\section{MATERIALS and METHODS}

Preoperative inferior mesenteric angiography was performed on 41 cases with rectal carcinoma (except anal carcinoma) from June 1980 to July 1987. The male / female ratio was 25 to 16 and patients ranged in age from 29 to 75 (mean, 58.4 years of age). Abdominoperineal resection was performed on 33 cases. 5 of them had hepatic metastasis. Colostomy only was performed on the other 8 cases due to severely invading tumor and / or hepatic metastasis. Except for 5 resected cases with hepatic metastasis, 28 cases without hepatic metastasis were followed up until March 1988.

The inferior mesenteric angiography was performed $30 \mathrm{sec}$. after administration of Prostaglandin $\mathrm{E}_{1}$ dissolved in $10 \mathrm{ml}$ of physiological saline solution into the inferior mesenteric artery. As a contrast medium, 10$15 \mathrm{mll}$ of $76 \%$ Urographin was injected at a rate of $4-6 \mathrm{ml} / \mathrm{sec}$.

The film program setting was 2 films / sec. $\times 3$ seconds, 1 film / sec. $\times 4$ seconds and 5 films / sec. $\times 10$ seconds. The rectum was inflated by using an inserted Nelaton catheter in order to recognize the location of the carcinoma.

Taking into consideration our classification of angiographic findings of carcinoma of the colon (10), angiographic findings were classified into 4 groups as follows (Fig. 1):

$\mathrm{AG}-\mathrm{A} 3$, occlusion and / or encasement up to the first branches (right and / or left branches) of the superior rectal artery, similar to the marginal artery (Fig. 2);

$A G-A 2$, above mentioned abnormal findings up to the second branches (small branches of the first branch) of the superior rectal artery, similar to vasa recta (Fig. 3);

$A G-A 1$, abnormal findings on the third branches within the rectal wall of the superior rectal artery (Fig. 4 ); and $\mathrm{AG}-\mathrm{A} 0$, no $\mathrm{ab}$ normal findings on the arterial system around the rectum.

According to these angiographic classifications, 1) The incidence rates of postoperative recurrence were studied during the follow-up period, and 2) Angiographic findings were compared with histological adventitial invasion, venous and lymphatic invasion within the rectal wall.

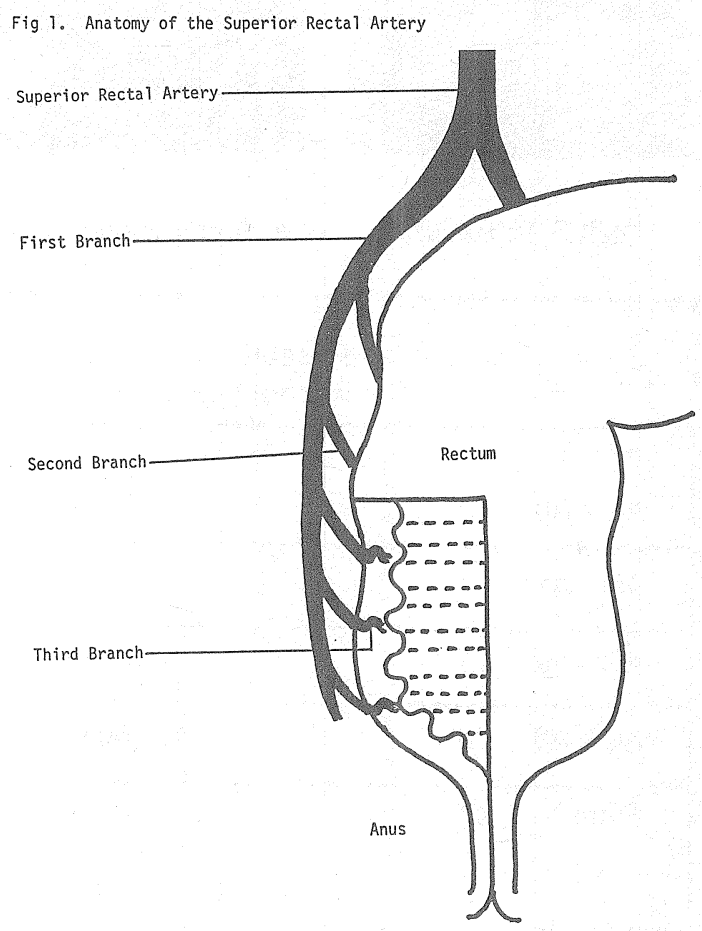


Fig. 2. $A G-A 3$

a) Barium Enema

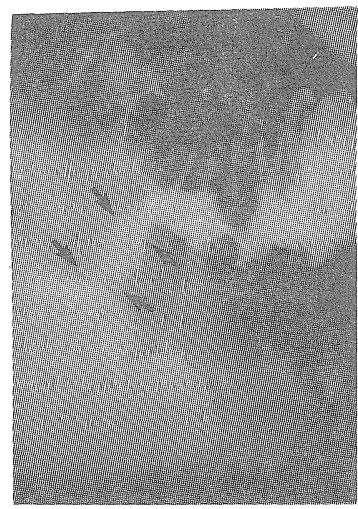

Fig. 3. AG-A2

a) Barium Enema

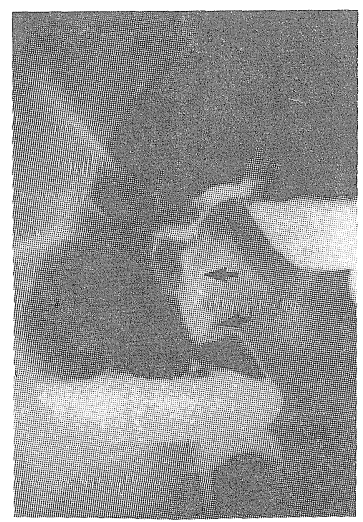

b) Angiography

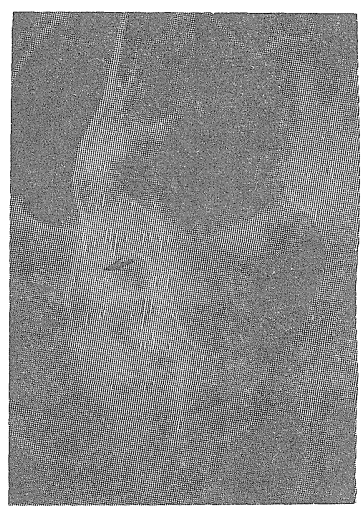

b) Angiography

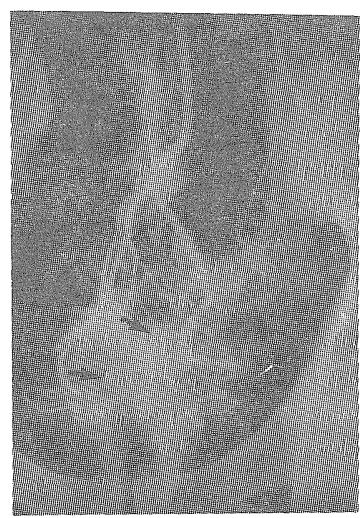

Fig. 4. AG-A1

a) Barium Enema

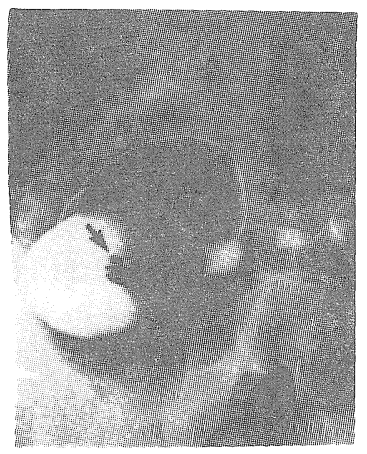

RESULTS

According to the angiographic findings, the 41 cases were classified as follows: AGA3, 20 cases; AG-A2, 15 cases; AG-A1, 4 cases and $A G-A 0,2$ cases. The 28 cases without hepatic metastasis, on which abdominoperineal resection was performed, were classified as follows: AG-A3, 10 cases $(50,0$ $\%) ; \mathrm{AG}-\mathrm{A} 2,12$ cases (80.0\%); AG-A1, 4 cases $(100 \%)$ and $\mathrm{AG}-\mathrm{AO}, 2$ cases $(100 \%)$. The resected cases with hepatic metastasis were 2 cases in $\mathrm{AG}-\mathrm{A} 2$ and 3 cases in $\mathrm{AG}-\mathrm{A} 3$ respectively.

In the course of the follow-up period for 28 resected cases without hepatic metastasis, recurrence appeared in one case $(25.0 \%)$ out of 4 cases of $A G-A 1$, in 3 cases $(25.0 \%)$ out of 12 cases of AG-A2 and 5 cases (50.0\%) out of 10 cases of $\mathrm{AG}-\mathrm{A} 3$.

These data are summarized in Table 1.

TABLE 1: Recurrence after Abdominoperineal Operation

\begin{tabular}{|llccc|}
\hline Cases & $\begin{array}{l}\text { Resected cases } \\
\text { without hepatic metastasis }\end{array}$ & Recurrence & $\begin{array}{c}\text { Time of diagnosis } \\
\text { for recurrence }(\mathrm{m})^{x}\end{array}$ \\
\hline AG - A0 & 2 & $2(100)$ & $0(0)$ & \\
\hline AG - A1 & 4 & $4(100)$ & $1(25.0)$ & 23 months \\
\hline AG - A2 & 15 & $12(80.0)$ & $3(25.0)$ & $9-52$ months (mean; 32.3) \\
\hline AG - A3 & 20 & $10(50.0)$ & $5(50.0)$ & $5-26$ months (mean; 11.6) \\
\hline Total & 41 & $28(68.3)$ & $9(31.0)$ & $(\%)$ \\
\hline
\end{tabular}


TABLE 2: Comparison of Angiographic Findings with Histological Invasion

\begin{tabular}{|lccccc|}
\hline Cases & & Adventitial invasion & Venous invasion & Lymphatic invasion \\
\hline AG $-\mathrm{A} 0$ & 2 & $0(0)$ & $1(50.0)$ & $0(0)$ \\
\hline $\mathrm{AG}-\mathrm{A} 1$ & 4 & $1(25.0)$ & $2(50.0)$ & $2(50.0)$ \\
\hline $\mathrm{AG}-\mathrm{A} 2$ & 12 & $4(33.3)$ & $7(58.3)$ & $6(50.0)$ \\
\hline AG $-\mathrm{A} 3$ & 10 & $5(50.0)$ & $7(70.0)$ & $7(70.0)$ \\
\hline Total & 28 & $10(35.7)$ & $17(60.7)$ & $15(53.6)$ \\
& & & $(\%)$ \\
\hline
\end{tabular}

The 2 cases of AG-A0 showed no adventitial and lymphatic invasion, but one case $(50.0 \%)$ showed venous invasion. Out of 4 cases of AG-A1, adventitial invasion was seen in one case $(25.0 \%)$, venous and lymphatic invasion were noted in 2 cases $(50.0 \%)$ respectively. Out of 12 cases of AG-A2, adventitial invasion was identified in 4 cases $(33.3 \%)$, venous invasion in 7 cases $(58.3 \%)$ and lymphatic invasion in 6 cases $(50.0 \%)$. Out of 10 cases of AG-A3, adventitial invasion was noted in 5 cases $(50.0 \%$ ), venous invasion in 7 cases $(70.0 \%)$ and lymphatic invasion in 7 cases $(70.0 \%)$.

All data can be seen in Table 2 .

\section{DISCUSSION}

Since many patients are suffering from postoperative recurrence of rectal carcino$\mathrm{ma}$, it is very important to predict preoperatively the possibility of the recurrence of rectal carcinoma after surgery.

According to the advancement of the carcinoma from the mucosa to the surrounding tissues around the rectum, the angiographic classifications were made up into $\mathrm{AG}-\mathrm{A0}$, $\mathrm{AG}-\mathrm{A} 1, \mathrm{AG}-\mathrm{A} 2$ and $\mathrm{AG}-\mathrm{A} 3$. Concerning the resectability of the carcinoma, all cases of $\mathrm{AG}-\mathrm{A} 0$ and $\mathrm{AG}-\mathrm{A} 1$ were removed and they had no hepatic metastasis. Twelve cases $(80.0 \%$ ) out of 15 cases of AG-A2 and 10 cases $(50.0 \%$ ) out of 20 cases of AG-A3 had no hepatic metastasis and were resected. Taking hepatic metastasis in to consideration, the resectability is a little higher, in 14 cases (93.3\%) of AG-A2 and in 13 cases (65.0 $\%)$ of $A G-A 3$. This is due to the development of therapeutic methods. Recently in Japan, hepatic metastasis has been actively treated by transcatheter arterial embolization and enucleation of tumors $(11,12)$. Therefore hepatic metastases are not particularly the cause of unresectability.

All the 28 resected cases were followed up until March 1988. During the follow-up period, the recurrence was found in one case (25.0\%) of AG-A1, in 3 cases $(25.0 \%$ ) of AG$\mathrm{A} 2$ and in 5 cases $(50.0 \%$ ) of $\mathrm{AG}-\mathrm{A} 3$, respectively. There has been no recurrence in the cases of $\mathrm{AG}-\mathrm{A} 0$. Considering the location of angiographic findings on tributaries of the superior rectal artery of the intra-or extrarectal wall, the rate of recurrence of the former groups, $\mathrm{AG}-\mathrm{A} 0$ and $\mathrm{AG}-\mathrm{A} 1$, was $16.7 \%$ (one case out of 6 cases) in contrast to $36.4 \%$ of the latter groups, AG-A2 and AG-A3 (8 cases out of 22 cases). So there is a definite correlation between the angiographic findings and postoperative recurrence. About the time of diagnosis for the recurrence, one 
recurred case of AG-A1 was 23 months. It was 9 to 52 months (mean; 32.3 months) in 3 cases of AG-A2 and 5 to 26 months (mean; 11.6 months) in 5 cases of AG-A3. In regard to the form of recurrence at the time of diagnosis, one case of AG-A0 was local recurrence. Out of cases of AG-A2, two showed local recurrence and one was hepatic metastasis. Among 5 recurred cases of AG-A3, four showed carcinomatous peritonitis and only one had local recurrence. The rates of local recurrence to all forms of recurrence of AG-A1, AG-A2 and AG-A3 are $100 \%, 66.7$ $\%$ and $20.0 \%$. Accordingly, in the cases of AG-A2 and AG-A3, cancer would undoubtedly invade surrounding tissues around the rectum more deeply. According to Igarashi's study about the mode of formation of local recurrence for rectal carcinoma (13), the causes of local recurrence are as follows: lymphatic stream ( $41.0 \%)$, external surgical surface $(23.0 \%)$, implantation $(3.3 \%)$, anal stump $(1.6 \%)$, venous stream $(1.6 \%)$ and unclassified $(29.5 \%)$. Therefore the major causes of local recurrence are lymphatic and adventitial invasions. Igarashi's rate of local recurrence caused by venous invasion is very low, $1.6 \%$, and it is supposed that venous invasion might be related to hepatic metastasis more closely as suggested in the report of the author about the correlation between angiographic venous invasion and hepatic metastasis for colon carcinoma (14). Accordingly we could decide that the main causes of recurrence are venous invasion, adventitial and lymphatic invasions. Also we need to know more about the correlations between histological and angiographic findings. In comparison of the angiographic classifications with histological invasions, angiographic findings and adventitial invasion are well correlated, their rates are $0 \%$ in $\mathrm{AG}-\mathrm{A} 0,25.0 \%$ in $\mathrm{AG}-\mathrm{A} 1,33.3 \%$ in $\mathrm{AG}$ $\mathrm{A} 2$ and $50.0 \%$ in AG-A3. Regarding the comparison between angiographic findings and lymphatic invasion, the rates are $0 \%$ in $\mathrm{AG}-\mathrm{A} 0,50.0 \%$ in both $\mathrm{AG}-\mathrm{A} 1$ and $\mathrm{AG}-\mathrm{A} 2$, and $70.0 \%$ in $\mathrm{AG}-\mathrm{A} 3$, indicating relative correlation. As to the angiographic findings compared to venous invasion, there is a distinct difference from adventitial and lymphatic invasion. The rate of $\mathrm{AG}-\mathrm{A} 0$ is $50.0 \%$. Furthermore the rates of AG-A1, AG-A2 and $\mathrm{AG}-\mathrm{A} 3$ are $50 \%, 58.3 \%$ and $70.0 \%$. The reason for venous invasion in the cases of $A G-$ A0 might be due to the trend to dilate rectal venous system due to stasis. We plan to study the correlation between angiographic findings and venous invasion related to hepatic metastasis.

When abnormal findings are noted in extrarectal tributaries of the superior rectal artrery on preoperative angiogram, the possible recurrence rate is $36.4 \%$. Especially, in the case of abnormal findings in the branch of the superior rectal artery ( $A G-A 3$ ), the rates of histological adventitial, venous and lymphatic invasions are $50.0 \%, 70.0 \%$ and $70.0 \%$, respectively, and the recurrence occurs in $50.0 \%$ of the cases. As to AG-A1 and $\mathrm{AG}-\mathrm{A} 2$, the recurrence rate is the same, 25.0 $\%$, and there is no significant difference in the comparison of histological adventitial, venous and lymphatic invasions between AG-A1 and AG-A2, 25.0\% and 33.3\% in adventitial invasion, $50.0 \%$ and $58.3 \%$ in venous invasion, and $50.0 \%$ and $50.0 \%$ in lymphatic invasion, respectively, although 4 cases of AG-A1 is a small number. Because of high rates (over $50.0 \%$ ) of venous and lymphatic invasion even in the patients with minimal angiographic findings in all stages of the rectal carcinoma should be resected more radically and regional lymph nodes should be dissected completely. In every case, postoperative local radiation (9) and / or chemotherapy should be done quite soon after surgery.

\section{REFERENCES}

1) Cars A W, Million R R, Pfaff WW. Patterns of recurrence following surgery alone for adenocarcinoma of the colon and rectum. Cancer. 1976; 37: $2861-5$.

2) Pahlman L, Glimelius B. Local recurrence after surgical treatment for rectal carcinoma. Acta Chir Scand. 1984; 150: 331-5. 
3) Moosa A R, Ree P C, Marks J E, Levin B, Platz $C E$, Skinner D B. Factor influencing local recurrence after abdominoperineal resection for cancer of the rectum and rectosigmoid. BrJ Surg. 1975; 62: 727-30.

4) Reznek R H, White F E, Young J W R, Kesey F. The appearance on computed tomography after abdominoperineal resection for carcinoma of the rectum: a comparison between the normal appearance and those of recurrence. Br J Radiol. 1983; 56: 237-40.

5) Adalsteinsson B, Pahlman L, Hemmingsson $A$, Glimelius B, Graffin S. Computed tomography in early diagnosis of local recurrence of rectal carcinoma. Acta Radiol. 1987; 28: 41-7.

6) Adalsteinsson B, Glimelius B, Graffin S, Hemmingsson A, Pahlman L, Rimsten A. Computed tomography of recurrent rectal carcinoma. Acta $R a-$ diol. 1981; 22: 669-72.

7) Moss A A, Thoeni R F, Schnyner P, Margulis A. Value of computed tomography in the detection and staging of recurrent rectal carcinoma. I Com Assis Tom. 1981; 5: 870-4.

8) Freeny P, Mark W M, Ryan J A, Bolen J W. Colerectal carcinoma evaluation with CT: Preoperative staging and detection of postoperative staging and detection of postoperative recurrence. Radiology. 1986; 158: 347-53.
9) Nakano $G$, Nakamura T, Kimura $H$, Hoshi $H$, Takenoshita S, Shoda H, Niibe H. Postoperative open radiation theraphy for rectal carcinoma below the perineal reflection. I Jpn Soc Cancer Ther. 1986; 21: 467.

10) Iijima T. Angiographic diagnosis of the degree of serosal invasion of carcinoma of the colon. Dis Col Rect. 1988; 31: 46-9.

11) Okuyama K, Onoda S, Tohnosu N, et al. Evaluation of treatment for colorectal cancer patients with liver metastasis. IJap Soc Col Proctocol. 1988; 41: 26-33.

12) Iijima $T$, Nakano $G$, Kogure $K$, Kojima $T$, Osumi M, Nakamura T. Pathological Study of resected and dissected malignant hepatic tumors treated by arterial embolization and one shot intraarterial infusion chemotheraphy. Kitakantouigaku. 1985; 35: $481-6$.

13) Igarashi $T$. Clinicopathological studies on local recurrence (Pelvic reference and the mode of formation) of rectal carcinoma -with special reference to the mode of formation-. J Jap Soc Proct. 1986; 39: $361-72$.

14) Iijima T. Pharmacoangiographic diagnosis of venous invasion of carcinoma of the colon with reference to liver metastasis. Dis Col Rect. 1988; 31: $718-22$. 